\title{
Conservation, Utilization, Genetic and Chemodiversity of Germplasm of Genipap (Genipa Americana L.) in Brazil
}

\author{
Alex Souza De Jesus ${ }^{1}$, Jose Guedes Da Sena Filho ${ }^{2}$, Adenir Vieira Teodoro ${ }^{2}$, Milena Nascimento Cardoso ${ }^{1}$, Ana \\ Letícia Sirqueira Nascimento ${ }^{1}$, Ana Da Silva Ledo ${ }^{2}$ and Ana Veruska Cruz Da Silva ${ }^{2 *}$ \\ ${ }^{1}$ Universidade Federal de Sergipe, Brazil \\ ${ }^{2}$ Embrapa Tabuleiros Costeiros, Brazil
}

Submission: February 21, 2019; Published: March 22, 2019

*Corresponding author: Ana Veruska Cruz da Silva, Embrapa Tabuleiros Costeiros, Brazil

\begin{abstract}
Genipa americana L. or genipap (Rubiaceae) is brazilian native species. Its leaves and fruits are used in the folk medicine and are greatly consumed in natura in the form of sweets, juices, composts and wines. Moreover, it can be used for the recovery of contaminated soils, in civil and naval construction, dye production for fabric dyeing, ceramic artifacts and non-permanent tattoos. Phytochemical analysis from the leaves and fruits reported in the literature detected the presence of iridoids, monoterpenoids, fatty acids, steroids, carboxylic acids and phenolic compounds, some of which bioactive compounds.
\end{abstract}

Despite the economic and ecological importance, this species has suffered a considerable loss of genetic variability caused, mainly, by the expansion of farming areas in the Brazilian. The genetic diversity and structure of a Genipap Genebank and natural populations has been evaluated using molecular markers, generating data useful to help programs of plant breeding, prospection and conservation. Application of techniques of tissue culture overcome the difficulties imposed by the traditional genipap propagation system, enabling large-scale multiplication and the conservation of this Rubiaceae.

Keywords: Molecular characterization; Micropropagation; Tropical fruits

Abbreviations: ESTs: Expressed Sequence Tags; AS: Acclimatization Sabinópolis; CZAL: Ruz Das Almas; NB: Núcleo Bandeirante

\section{Introduction}

Genipap (Genipa americana L. - Rubiaceae) is a species widely distributed in tropical Central and South America, including the Cerrado biome [1]. Is a native from Amazon region, with medicinal importance and is widely used in Brazil [2]. This tree is one of the most promising for sustainable harvesting programs and restoration of Brazilian riparian forests [3] (Figure 1). G. americana has economic and environmental importance, being valued for food production, recuperation of degraded areas, in the composition in areas of permanent preservation and agroforestry $[3,4]$. Your wood is widely used in civil and naval construction, and carpentry [5].

Extractivism is the most common form of exploration of this species. Commercial uses, however, has been encouraged and is especially recommended in the recovery of degraded areas and contaminated soils [3]. In addition, the commercialization as fresh fruit has promising development, being held in the free trade fairs, in wholesale markets and supermarkets [6]. They are alternative foods for the population who live in these regions, contributing considerably to tropical forests conservation [7].

Unripe Fruits (green color) produces a blue to black juice that is used to tattoo the body [8], whereas ripe fruits were greenishbrown and possessed a soft, thin and wrinkled exocarp. The mesocarp is fleshy, yellow, and sweet and each fruit contained 105 $( \pm 10.7)$ seeds on average [9].

The tree is heliophytic, semideciduous, and selectively hygrophytic, occurring in areas with open forests and secondary vegetation of floodplains located in temporary or permanent locations flooded [5]. It is a late secondary, with climax characteristics, moderate growth and can be used urban afforestation.

\section{Genipap uses}

Besides the ecological and economic importance, it is worth mentioning the medicinal various parts of the plant being used in 
the medicine in many regions of the country [2]. Commercializing and validation of its benefits is employed in a folk medicine [8].

The fruits, leaves and bark are indicated in cases of cough, anemia, bruises, dislocations, as well as purgative, diuretic, osteoporosis, stomach problems, nervousness, diabetes, cholesterol, besides being excellent tonic in the fight against the indisposition, fatigue and weakness [10]. Satisfactory amounts of iridoids, tannins, and genipacetol, with pharmacological activity [2].

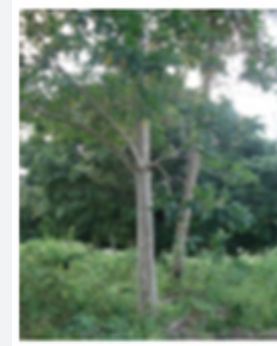

(A)

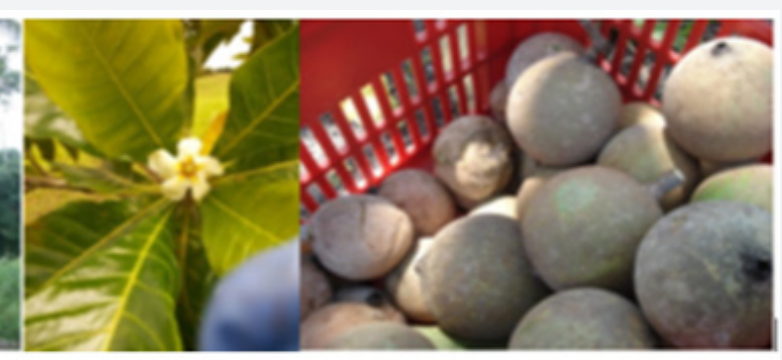

(B)
(C)

Figure 1: Tree (A), flower (B) and fruits (C) of Genipa americana L.

Roots showed antigonorrheal properties and the decoction its leaves are used for diarrhea and syphilis [8]. An ethnopharmacological survey carried out in the rural area of Serra da Raiz, Paraíba state, Northeastern Brazil, showed that genipap is one of the main species that are widely used in the treatment of various diseases, such as respiratory problems, inflammation and blood diseases [10]. Moreover, because of its high mannitol content, the fruit is recommended for its antihypertensive properties [8]. In the industry, it is employed to production of hair, skin products and natural skin dyes.

In North and Northeast regions of Brazil, fruits have potential due to high nutritive value and lipid content [7]. Genipap in natura have considerable moisture values, e.g. total carbohydrates, mainly dietary fiber, vitamin $\mathrm{C}$ and phenolic compounds and high antioxidant activity. Therefore, the inclusion of genipap in the diet could improve its quality, contributing to food and nutritional security of the cerrado population. In food it can be used in natura in preparations or in beverages e. g. jams, candies, crystallized, liqueurs, juice, wine and brandy [11].

\section{Chemical composition}

The first studies of isolation, characterization, and structural elucidation of the bioactive compounds of genipap were the iridoid genipin in the early 60s [12]. In isolated genipic acid and genipinic acid obtained from fruit extracts [13]. Geniposidic acid was the only glycosylated iridoid isolated from the methanolic extract of G. americana leaves until the present moment [14]. Later, the isolation of the geniposid was carried out and the tarennoside, gardenoside, and geniposidic acid were obtained by callus formation and culture of suspended cells [15].

Steroids have been reported in the composition of fruits extract, but not confirmed the occurrence of sesquiterpene, flavonoids, or other secondary compounds (Table 1). The absence of terpenoids, specially the sesquiterpenes may be explained by some aspects of plant collection, such as botanic diversity or stage of maturation of the fruit [9]. For the Recôncavo Baiano Region there are variability in the chemical constituents of genipap fruit characters, such as, $\mathrm{pH}$, soluble solids content and ascorbic acid. This data suggest economic exploitation of fruits for consumption in natura and industrialization [6].

Table 1: Chemical composition from de fruits and leaves of $G$. Americana

\begin{tabular}{|c|c|c|}
\hline Part of plant & Compound & Reference \\
\hline Fruits & Steroids & {$[8]$} \\
\hline & $\begin{array}{c}\text { Geniposide, genipin gentiobioside, and } \\
\text { 5-caffeoylquinic acid }\end{array}$ & {$[16,17]$} \\
\hline & Genipin & {$[18]$} \\
\hline & Genipaol,and ranolazine & {$[17]$} \\
\hline & Fatty acid & {$[7]$} \\
\hline & Gonoterpenoids and iridoids & {$[19,20]$} \\
\hline & carboxylic acids, linalool and limonene. & {$[21,22]$} \\
\hline $\begin{array}{c}\text { Fruits, leaves } \\
\text { and }\end{array}$ & Geniposide, geniposidic acid & {$[15]$} \\
\hline Leaves & Geniposidic acid & {$[14]$} \\
\hline
\end{tabular}

The influence of the ripeness stage of genipap fruits on their iridoid and phenolic compound composition by high-performance liquid chromatography connected in series to a diode array detector and mass spectrometer HPLC-DAD-MSn, was performed. A total of 17 compounds, among them, compound phenolic and iridoids were identified in genipap fruits, native to the Amazon region [16-20].

The volatile fraction of the Genipap fruits has high amounts of carboxylic acids (butyric, 2-methylbutyric and hexanoic acids) and 2- and 3-methylbutyric acids, which are probably related to the strong and primary odor of genipap [21]. Seven new iridoid called genamesides A-D, genipacetal, genipamide and genipaol were isolated from its fruits along with eight known iridoid glucosides: geniposidic acid, geniposide, gardenoside and 
genipin-gentiobioside, genipin, gardendiol, deacetyl aperuloside acid methyl ester and shanzhiside were reported in the fruits $[19,20]$. Besides the identified of carboxylic acids, alcohols, esters and aromatic compounds, in the volatile fraction, as well as the monoterpenes: linalool and limonene [22,23].

In this context, the high chemodiversity of iridoids in the fruits and the nutritional source of this specie shed a light to investigate the secondary metabolites of the G. americana, in order to provide data to characterize the available germplasm to serve as a basis for the production of bioactive compounds with agroindustrial and pharmacological potential. Nowadays, techniques are exploring bioactivity compounds and new drugs formulations are being made in medicinal plants, but the understanding of the biosynthesis and the genetic variability this species need to be complete understand.

\section{Genetic diversity}

The farming expansion areas in the Brazilian has been caused considerable loss of variability genetic, although genipap occurs natural reserves and indigenous lands. Genetic markers can used in forest ecosystems enables advances in the genetic understanding of the natural populations, as well as assists on strategies to recover or restore forests [24].

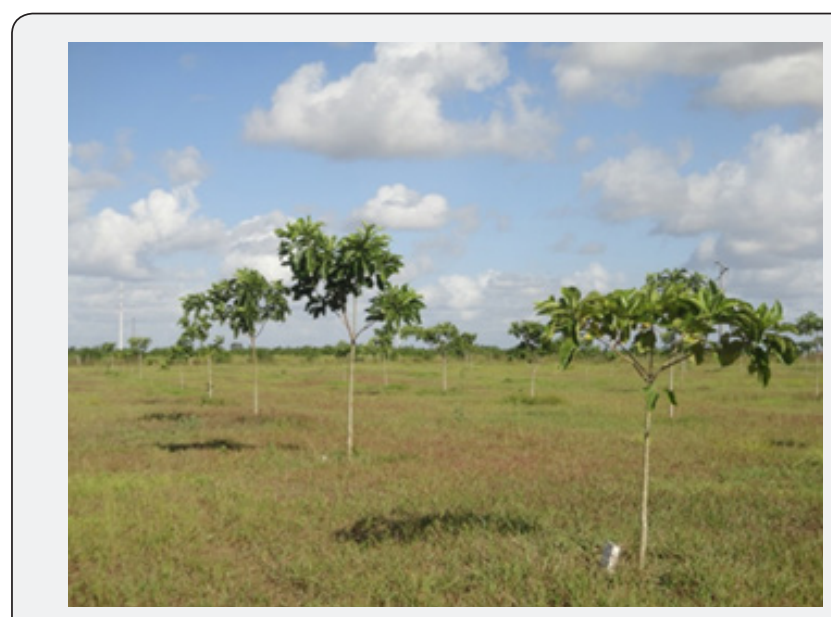

Figure 2: Genipap Genebank of Embrapa Tabuleiros Costeiros Nossa Senhora das Dores, Sergipe, Brazil.

Regarding the high potential of the genipap for conservation of its genotypes, the Genipap Genebank was created in 2009 at the

Brazilian Enterprise for Agricultural Research-Embrapa Coastal Tablelands, in the city of Nossa Senhora das Dores, in the state of Sergipe, Brazil $\left(10^{\circ} 27^{\prime} 50,0^{\prime \prime}\right.$ S and $37^{\circ} 11^{\prime} 39,5^{\prime \prime}$ W), consisting of 160 accessions from wild populations (Figure 2). Genipap Genebank is accredited by the Genetic Heritage Management Council (CGEN), a normative and deliberative organ of the Brazilian Ministry of Environment (MMA), as faithful custodian of the genipap genetic patrimony (process number 2000.002275/2013-36) [25].

The Genebank of Embrapa is compound by just two species: G.americana L. and G. infundibuliformis Zappi \& Semir (Table 2). The development of studies of chemical and biological characterization accessions that compose the genotype genebank can generate data useful to help programs of plant breeding. The activities developed include prospection, collection, ex situ conservation, development of in vitro conservation protocols, morphological and molecular descriptor-based characterization, filing and documentation.

The genetic diversity and structure of genebank was evaluated using inter simple sequence repeat (ISSR) markers. The data generated from 12 ISSR primers were used to determine genetic variability via a model-based Bayesian procedure (Structure) and molecular variance analysis [3]. A total of 12 primers were used, which generated 123 polymorphic fragments. Four groups were formed from the analysis of the fragments, and the CR1-2 genotype was isolated, being more divergent than the other genotypes [3]. This data can be used in the reclassification of accessions in future breeding and conservation programs.

Recent manuscript reported the mendelian inheritance, genetic linkage, and genotypic disequilibrium at six microsatellite loci developed for $G$. americana [5]. Results detect genetic linkage between pairwise loci in $54.4 \%$ of the tests, but no genotypic disequilibrium was detected between pairwise loci for adult trees and regenerants [5].

The molecular characterization of accessions was performed using 15 inter-simple sequence repeat (ISSR) primers, and genotype clustering was performed based on genetic dissimilarity using the Unweighted Pair-Group Method with Arithmetic Mean (UPGMA). The NB (Núcleo Bandeirante) accession is genetically different from the CZA (Cruz das Almas) and AS (Sabinópolis) populations and shows superiority for most of the variables analyzed [26].

Table 2: Genotype origins of Genipa americana L. from Genipap Genebank of Embrapa Tabuleiros Costeiros. Nossa Senhora das Dores, Sergipe, Brazil.

\begin{tabular}{|c|c|c|c|}
\hline Code of Accession & Origin/State & Specie & \multicolumn{1}{|c|}{ N. of individuals } \\
\hline BA & Recôncavo Baiano, Bahia & Genipa infundibuliformis Zappi \& Semir & Genipa americana L. \\
\hline CR1 & Criolo, Sergipe & Genipa americana L. \\
\hline CR2 & Lagarto, Sergipe & Genipa americana L. \\
\hline CR3 & Lagarto, Sergipe & Genipa americana L. \\
\hline CR4 & Lagarto, Sergipe & Genipa americana L. \\
\hline CR5 & Lagarto, Sergipe & Genipa americana L. \\
\hline AJ & Aracaju, Sergipe & 10 \\
\hline
\end{tabular}




\begin{tabular}{|c|c|l|c|}
\hline CA & Caueira, Sergipe & Genipa americana L. & 10 \\
\hline AR1 & Arauá, Sergipe & Genipa americana L. & 10 \\
\hline AR2 & Arauá, Sergipe & Genipa americana L. & 10 \\
\hline AR3 & Arauá, Sergipe & Genipa americana L. & 10 \\
\hline AR4 & Arauá, Sergipe & Genipa americana L. & 5 \\
\hline MA & Maruim, Sergipe & Genipa americana L. & 10 \\
\hline LA & Laranjeiras, Sergipe & Genipa americana L. & 8 \\
\hline CV & Cascavel, Ceará & Genipa americana L. & 9 \\
\hline MS & Men de Sá Island, Sergipe & Genipa americana L. & 8 \\
\hline SO & N. Sra. doSocorro,Sergipe & Genipa americana L. & 10 \\
\hline IT & Itaporanga d Ajuda, Sergipe & Genipa americana L. & 10 \\
\hline BO1 & Boquim, Sergipe & Genipa americana L. & 10 \\
\hline BO2 & Boquim, Sergipe & Genipa americana L. & 8 \\
\hline SA & Sabinópolis, Distrito Federal & Genipa americana L. & 10 \\
\hline SDV & Salto da Divisa, Minas Gerais & Genipa americana L. & 9 \\
\hline CRA & Cruz das Almas, Bahia & Genipa americana L. & 217 \\
\hline CER & Núcleo Bandeirante, Distrito & Genipa americana L. & \\
\hline
\end{tabular}

In Sergipe state, in the lower course of São Francisco River, the genetic diversity among 18 individuals of G. americana by RAPD markers using 12 primers, was evaluate. Results showed the Jaccard index, the average genetic similarity (Ags) among individuals was $60.4 \%$, while the highest similarity distance obtained is between individuals G11 and G12 (83.6\% \pm 0.03$)$ and the lowest genetic similarity between individuals G4 and G18 $(36.5 \% \pm 0.02)$. Seven pairs were considered genetically similar based on the Ags 78.4\% [24]. This data can be used to provide seeds in combination with other individuals in restoration programs for degraded areas and adequate management of forest population [24].

A construction of cDNA library generated 165 expressed sequence tags (ESTs), in G. americana plants cultivated in nutritive solution. The results show 81 homology to genes deposited in the NCBI database, 67 did not show similarity to any available gene, and 17 ESTs demonstrated homology with unknown genes [27]. These genes probably associated with proteins and enzymes related to the defense mechanisms under biotic and abiotic stresses [27].

The genetic variability for the biochemical characteristics of seeds was performed in two populations: one from Ilha Solteira, SP region (ISA) and other from Mogi Guaçu, SP (MOG) show a great genetic variation. [28]. Narrow sense heritability estimates of progenies were moderate $(0.69$ for carbohydrates in the population ISA) to high ( 0.81 to 0.99 for the other traits in the two populations), indicating that much progress can be expected with selection strategies [28].

The use of biochemical and molecular markers for characterization of genotypes useful for generating information in future utility in specific breeding program and allows for the identification of duplicates and germplasm exchange between researchers [29,30].

\section{Conservation}

Indigenous fruits are very important as sources of food security, balanced households nutrition [31]. Studies the seed bank species is important information for the conservation strategy in situ. In addition, induce seed bank can contribute for their regeneration, maintenance and establishment of seedlings [32]. G. americana seeds forms a transitory seed bank, with maintenance of its viability until the fourth month after disposal in natural environment. In general, the seed bank located in the riparian forest area showed the best potential for seedling establishment in a natural environment, which supports the ecological behavior of this species [32].

G. americana showed easy propagation by seeds, presenting between 83 and $92 \%$ of emergency. However, the process is slow, asynchronous and with low uniformity. These characteristics are sources of great heterogeneity in the development of the plants, which may hinder the conduction of cultural treatments in nurseries producing seedlings [33]. Another factor that affected to vigor and germination is the water restriction. Understanding of plant tolerance to drought is important especially for recovery of areas where there are problems with water stress for reasons climatic conditions or soil type conditions [34]. Moreover, this information is important because genipap is found riparian forest regions, is subject to flooding and dried, that is, its fruits are exposed to variations conditions that affect watercourses, which may compromise the maintenance of the species throughout time [34].

Genipap is classified as intermediate, because do not support low temperatures for extended periods. In function of this, the 
best strategy is used the filed collections, not being indicated conservation way seed bank $[4,26]$. On the other hand, the application of techniques of tissue culture is important for species such as genipap to overcome the difficulties imposed by the traditional propagation system, enabling large-scale multiplication and the conservation of this species with holds good prospect for the future (Figure 3) [35-37]. Domestication of these trees can be successful only if successful propagation techniques are applied [31]. Therefore, the optimal conditions for in vitro germination of $G$. americana seeds requires pre-soaking in distilled water for 48 hours and inoculation into culture media consisting of $1 / 2 \mathrm{MS}+15 \mathrm{~g} \mathrm{~L}^{-1}$ sucrose, with stratification in the dark for 16days, followed by the transfer to growth chambers with lighting provided by white fluorescent lamps [37].

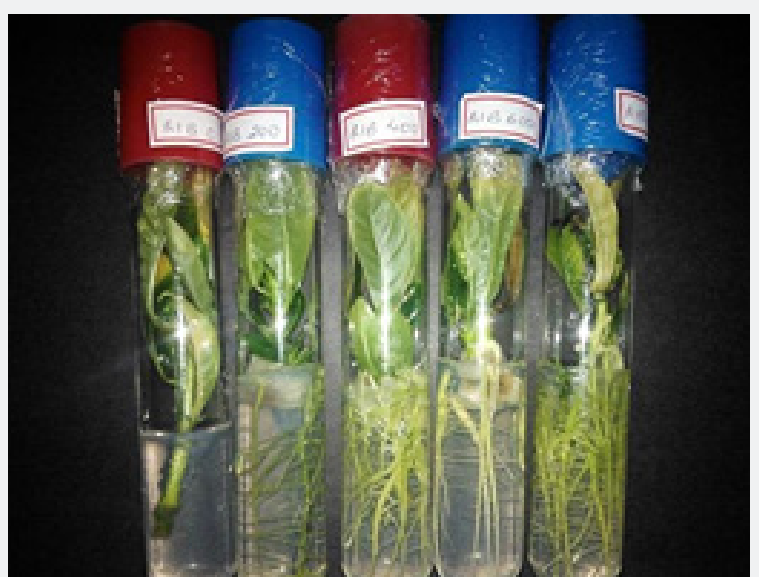

Figure 3: In vitro propagation of Genipa americana L. (Source: Ana da Silva Ledo).

The temperature for germination for genipap is $25^{\circ} \mathrm{C}, 30{ }^{\circ} \mathrm{C}$ and $35^{\circ} \mathrm{C}$ and the substrate is vermiculite and soil substrates were the best conditions for seed germination [38]. The substrates consisting of washed sand + dried coconut shell powder, at a 1:1 ratio by volume, and Topstrato HT® may be recommended for genipapo acclimatization Sabinópolis (AS), Cruz das Almas (CZA) and Núcleo Bandeirante (NB) accessions [26].

Drying seed genipap can be done in a greenhouse (temperature of $33^{\circ} \mathrm{C}$ with relative humidity of $70 \%$ ) for 24 hours or laboratory environment (temperature of $28^{\circ} \mathrm{C}$ with relative humidity of $75 \%$ ) for 48 hours without compromising the physiological quality [33]. For the immersed seeds in PEG solutions, the potential $-0.3 \mathrm{MPa}$ allowed the osmotic conditioning, while the -0.4 MPa interfered in vigor. In imbibed seeds in paper there was a germination reduction, because the time, until potential events were not observed from -0.3 MPa [33].

The of plant tolerance to drought and how to exploit them, especially with regard to problems of a physiological or ecological order, extremely important, especially for the recovery of areas where there are problems with water stress for reasons climatic conditions or soil type conditions.

Culture media supplementation with $1.0 \mathrm{mgL}^{-1}$ BAP favors the development of adventitious shoots and promotes a higher callogenesis percentage, leaf number and feasibility at 90 days of in vitro culture [26]. The immersion of the basal portion of shoots for 20 seconds in all IBA solutions induces the rhizogenesis in the genipap accessions at 90 days of in vitro culture [26]. In MS medium supplemented different concentration NAA in presence of BAP is possible in vitro regeneration of genipap from the conversion of zygotic embryos [36].

The cryoprotection and dehydration does not modify the viability of the shoot apices of genipap encapsulated or unencapsulated. Immersion for $24 \mathrm{~h}$ in cryoprotecting solution and the dehydration in a laminar flow cab by $2 \mathrm{~h}$ have potential for use in future studies of cryopreservation by encapsulationdehydration [4]. Due to potential use of genipap as food, technical strategies is need to use of tissue culture, to be used in mass propagation in large quantity.

\section{Conclusion}

Due to the recognized popular use of G. americana and to be a source of molecules with biological potential, research on conservation, management, sustainable utilization, marketing, ethnobotany, ethnopharmacology, food chemistry, pharmacology and genomics it is necessary more research for generate products of sustainable manner, low cost and environment friendly. Besides in understanding the chemodiversity of this particular species with a huge variety compounds.

\section{References}

1. Bailão EFLC, Devilla IA, Conceição EC, Borges LL ( 2015) Bioactive compounds found in Brazilian Cerrado fruits. Int J Mol Sci 16(1): 23760-23783.

2. Silva LA, Resende O, Virgolino ZZ, Bessa JFV, Morais WA, et al. (2015) Drying kinetics and effective diffusivity in jenipapo sheets (Genipa americana L.). Rev Bras Pl Med 17(4): 953-963.

3. Silva AVC, Freire KCS, Lédo AS, Rabbani ARC (2014) Diversity and genetic structure of jenipapo (Genipa americana L .) Brazilian accessions. Sci Agric 71(5): 345-355.

4. Sá FP, Souza FVD, Silva AVC, Lédo A S (2015) Encapsulation, dehydration and cryoprotection in regenerative capacity of shoot apices of Genipa americana. Ciên Rural 45(11): 1939-1945.

5. Manoel RO, Freitas MLM, Tambarussi EV, Cambuim J, Moraes MLT, et al. (2015) Mendelian inheritance, genetic linkage, and genotypic disequilibrium at microsatellite loci in Genipa americana L. (Rubiaceae). Genet Mol Res 14(3): 8161-8169.

6. Hansen DDS, Silva SA, Fonseca AAO, Hansen OADS, França NO (2008) Chemical characterization of native jenipapo fruits from the Recôncavo Baiano region aiming in naturafruit consumption and industrialization. Rev Bras Frutic 30(4): 964-969.

7. Costa PA, Ballus CA, Filho JT, Godoy HT (2011) Fatty acids profile of pulp and nuts of brazilian fruits. Ciênc Tecnol Aliment 31(4): 950-954.

8. Conceição AO, Rossi MH, Oliveira FF, Takser L, Lafond J (2011) Genipa americana (Rubiaceae) fruit extract affects mitogen-activated protein kinase cell pathways in human trophoblast-derived bewo cells: implications for placental development. J Med Food 14(5): 483-494.

9. Queiroz SEE, Silva EAA, Davide AC, José AC, Silva AT, et al. (2012) Mechanism and control of Genipa americana seed germination. Physiol Plant 144(3): 263-276. 
10. Cordeiro JMP, Félix LP (2014) Botanical medical knowledge of native species of the Caatinga and spontaneous plants in the Agreste region of the state of Paraíba, Brazil, Brasil. Rev Bras Pl Med 16(3): 685-692.

11. Pacheco P, Paz JG, Silva CO, Pascoal GB (2014) Centesimal composition, bioactive compounds, phisicochemical parameters in in natura jenipapo (Genipa americana L.). Demetra 9: 1041-1054.

12. Djerassi C, Budzikiewicz H, Wilson JM (1961) Mass-spectrometry in structural and stereochemical problems. XXXII. Pentacyclic triterpenes. J. Am. Chem. Soc. 85(22): 3688-3699.

13. Tallent WH (1964) Two new antibiotic cyclopentanoid monoterpenes of plant origin. Tetrahedron Lett 20(7): 1781-1787.

14. Guarnaccia KM, Madyastha E, Tegtmeyer J (1972) Geniposidic acid, an iridoid glugoside from Genipa americana. Tetrahedron Lett 13(50): 5125-5127.

15. Ueda S, Ahashi YA (1991) Production of anti-tumor-promoting iridoid glucosides in genipa americana and its cell cultures. J Nat Prod 54(6): 1677-1680.

16. Bentes AS, Mercadante AZ (2014) Influence of the stage of ripeness on the composition of iridoids and phenolic compounds in genipap (Genipa americana L.). J Agric Food Chem 62(44): 10800-10808.

17. Kumar B, Smita K, Cumbal L, Camacho J, Hernandez Gallegos E, et al. (2016) One pot phytosynthesis of gold nanoparticles using Genipa americana fruit extract and its biological application. Mater Sci Eng C Mater Biol Appl 62: 725-731.

18. Djerassi C, Gray JD, Kincl F, (1960) Isolation and caracterization of genipin. J Org Chem 25: 2174-2177.

19. Ono M, Ueno M, Masuoka C, Ikeda T, Nohara T (2005) Iridoid glucosides from the fruit of Genipa americana. Chem Pharm Bull 53(10): $1342-1344$

20. Ono M, Ishimatsu N, Masuoka C, Yoshimitsu H, Tsuchihashi R, et al. (2007) Three new monoterpenoids from the fruit of Genipa americana. Chem Pharm Bul 55(4): 632-634.

21. Borges ES, Rezende CM (2000) Main aroma constituents of genipap (Genipa americana L.) and Bacuri (Platonia insignis M.). J Essent Oil Res 12: 71-74.

22. Pino J, Marbot R, Vazquez C, Nacional C, Médica DG, et al. (2005) Volatile constituents of genipap (Genipa americana L.) fruit from Cuba Flavour and Fragrance Journal 20(6): 583-586.

23. Pinto AB, Guedes CM, Moreira RFA, Maria CAB (2006) Volatile constituents from headspace and aqueous solution of genipap (Genipa americana) fruit isolated by the solid-phase extraction method. Flavour and Fragrance Journal 21(3): 488-491.

24. Rabbani ARC, Silva Mann R, Ferreira RA (2012) Genetic variability of
Genipa americana L. Belonging to the lower course of São Francisco River. Rev Árvore 16: 401-409.

25. Muniz AVCS (2015) Genipap Active Genebank.

26. Sa FP, Ledo AS, Amorim JAE, Silva AVC, Pasqual M (2016) In vitro propagation and acclimatization of genipapo accessions. Ciênc agrotec 40(2): 155-163.

27. Souza VL, Almeida AAF, Júnior BTH, Gesteira AS, Cascardo JCM (2008) Preliminary analysis of expressed sequences of genes in Genipa americana L . plant roots exposed to cadmium in nutrient solution. Genet Mol Res 7(4): 1282-1288.

28. Oliveira SA, Bonjorno II, Alves PF, Marcela Aparecida de Moraes MLMF Polizeli MLT de M, et al. (2009) Genetic variation in biochemical traits in seeds of two natural populations of Genipa americana L. 1- individual and univariate analyses. Sci For 37: 71-78.

29. Bishun DP, Ganesh T, Samindra B, Sangita S (2011) Biochemical and molecular characterization of submergence tolerance in rice for crop improvement. J Plant Breed Crop Sci 3(10): 240-250.

30. Tripathi A, Mishra DK, Shukla JK (2015) Genetic diversity and trait association between growth, yield and seed component of Jatropha curcas (L.) source collection from Indian sub-continent. J Plant Breed. Crop Sci 7: 143-157.

31. Okuto G, Ouma J L (2009) Seed germination of java plum (Syzigium cumnii) in three provenances western Kenya. J Plant Breed Crop Sci 1(10): 320-329.

32. Salla F, José AC, Faria JMR (2016) Seleção de matrizes, coleta e beneficiamento das sementes. Cerne 22: 93-100.

33. Oliveira LM, Silva EO, Bruno RLA, Alves EU (2011) Periods and dry environments in the seeds quality of Genipa americana L. Semina Ciênc Agrár 32(2): 495-502.

34. Santos ARF, Silva Mann R Ferreira RA (2011) Restrição hídrica em sementes de Jenipapo (Genipa americana L.). Rev Árvore 35(2): 213-220.

35. Ighere DA, Okere A, Jammadine E, Olayode M, Fajimi O, et al. (2011) In-vitro culture of Hevea brasiliensis (rubber tree) embryo. J Plant Breed Crop Sci 3(9): 185-189.

36. Oliveira ACA, Machado CA, Oliveira LAR, Silva AVC, Lédo AS (2017) In vitro morphogenic response from zygotic embryos of Genipa americana. Ciênc Rural 47(10): 2016-2018.

37. Souza RR, Paiva PDO, Silva RR, Reis MV, Nery FC et al. (2016) Optimization of jenipapo in vitro seed germination process. Ciênc Agrotec 40(6): 658-664

38. Andrade CS, Souza AF, Ramos FN, Pereira TS, Cruz APM (2000) Seed germination of Genipa americana L. - Rubiaceae: temperature, substrate and post-seminal development. Ciênc Agrotec 35(3): 609-615.

This work is licensed under Creative

Commons Attribution 4.0 License

DOI: 10.19080/CTBEB.2019.18.555995 